\title{
Isolasi Dan Uji Aktivitas Kitinase Isolat Bakteri Dari Kawasan Geotermal Dieng
}

\author{
Hidayatun Nafiah, Sri Pujiyanto dan Budi Raharjo \\ Laboratorium Bioteknologi, Departemen Biologi, Fakultas Sains dan Matematika, \\ Universitas Diponegoro Jl. Prof. H. Sudharto, Tembalang, Semarang. \\ hidayatunafiah@gmail.com,spujiyanto@hotmail.com,budi206@yahoo.com
}

\begin{abstract}
Chitinase (EC.3.2.2.14) is an enzyme which can degradatechitin became N-acetilglucosamin. Chitinase has many benefits made the demand of it increases. High demands spur its availability in large quantities, cheap, fast production, resistant to any physical factor and chemical environment. Rapid and resistant enzyme production to environment factor can be obtained using chitinolitic bacteria of Geothermal Dieng. The utilization of chitin as bacterial growth substrate from waste of shell crab can be done considering high prices of commercial chitin on the market. The purpose of the research is to get the isolate of termoleranchitinolitic of watery mud in Geothermal Dieng and to know the character of the chosen isolate producing highest chinitase activity type of chitin source treatment and $\mathrm{pH}$ of media production. The research is done by growing the chitinolitic in the room temperature for 14 days. The experimental design used in this study is a complete randomized design of factorial pattern (two factors). The first factor is the type of chitin source that includes commercial chitin and chitin crab kits. The second factor is the $\mathrm{pH}$ of liquid chitin media for the production of enzymes, ie $\mathrm{pH} 6,7$ and 8.Chitinase activity is tested by measuring the result of sugar reduction. Obtained data is analyzed with Analysis of Variance (ANOVA). Result of isolation and selection is obtained one potential isolate, KSR 121. The isolate produce $1,4 \mathrm{~cm}$ of chitinolitic index after 96 hour incubation. Result of statistical test show both citin source type, $\mathrm{pH}$ of media production treatment and interaction were not significantly different $(\mathrm{P}>0,05)$. KSR 121 isolate experience the highest growth of crab chitin treatment $\mathrm{pH}$ 8 (K2P3) with 6 hour incubation, whereas highest kinitase activity happen on crab chitin treatment pH 7 (K2P2) with 24 incubation, in amount of $0,125(\mathrm{U} / \mathrm{mL})$.
\end{abstract}

Key words: N-acetil glucosamin, chtinase activity, chitinase, chitin, chitinolitic bacteria, isolation

\begin{abstract}
Abstrak
Kitinase (EC.3.2.2.14)merupakan enzim yang memecah kitin menjadi $N$-asetil glukosamin. Kitinase memiliki banyak manfaat, sehingga permintaan di pasar tinggi. Permintaan yang tinggi memacu ketersediaannya dalam jumlah banyak, murah, produksi cepat, tahan terhadap faktor fisik maupun kimia lingkungan. Produksi enzim yang cepat dan tahan terhadap berbagai faktor lingkungan dapat diperoleh dengan menggunakan bakteri kitinolitik dari daerah Geotermal Dieng. Kitin komersial di pasar harganya mahal, sehingga pemanfaatan kitin sebagai substrat pertumbuhan bakteri dari limbah cangkang rajungan dapat dilakukan. Penelitian bertujuan mendapatkan isolat bakteri kitinolitik termotoleran dari sampel lumpur berair di kawasan Geotermal Dieng serta mengetahui karakter isolat terpilih dalam menghasilkan aktivitas kitinase tertinggi dengan perlakuan jenis sumber kitin dan $\mathrm{pH}$ medium produksi. Rancangan percobaan yang digunakan dalam penelitian ini yaitu rancangan acak lengkap pola faktorial (dua faktor). Faktor pertama yaitu jenis sumber kitin yang meliputi kitin komersial dan kitin cangkang rajungan.

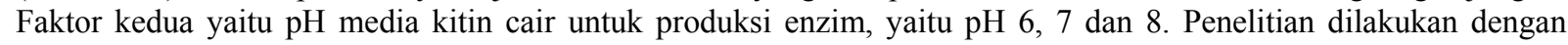
mengisolasi bakteri kitinolitik yang diinkubasi pada suhu ruang selama 14 hari. Aktivitas kitinase diuji dengan mengukur gula reduksi yang dihasilkan. Data yang diperoleh dianalisis dengan Analysis of Variance (ANOVA). Hasil isolasi dan seleksi diperoleh satu isolat potensial, yaitu KSR 121. Isolat menghasilkan indeks kitinolitik sebesar 1,4 cm setelah inkubasi 96 jam. Hasil uji statistik menunjukkan perlakuan jenis sumber kitin, variasi pH media produksi dan interaksi antara perlakuan jenis sumber kitin dan $\mathrm{pH}$ media produksi tidak berbeda nyata $(\mathrm{P}>0,05)$. Isolat KSR 121 mengalami pertumbuhan tertinggi pada perlakuan kitin rajungan $\mathrm{pH} 8$ (K2P3) dengan waktu inkubasi 6 jam, sedangkan aktivitas kitinase tertinggi terjadi pada perlakuan kitin rajungan $\mathrm{pH} 7(\mathrm{~K} 2 \mathrm{P} 2)$, waktu inkubasi 24 jam, sebesar $0,125(\mathrm{U} / \mathrm{mL})$.
\end{abstract}

Kata kunci: $N$-asetil glukosamin, aktivitas kitinase, kitinase, kitin, bakteri kitinolitik, isolasi 


\section{PENDAHULUAN}

Indonesia merupakan negara yang berada pada titik pertemuan tiga lempeng tektonik (Bird, 2003), sehingga Indonesia memiliki banyak sumber panas bumi. Sumber panas bumi yang ada di Indonesia memiliki banyak manfaat, diantaranya sebagai pembangkit listrik tenaga uap panas yang dilakukan oleh PLTP PT. Geodipa Energi, Dieng, Jawa Tengah. Potensi lain yang dapat dimanfaatkan yaitu dilakukannya eksplorasi bakteri yang dapat menghasilkan enzim termostabil. Bakteri merupakan salah satu mikroorganisme yang berperan untuk menghasilkan enzim, misalnya yaitu enzim kitinase. Kitinase memiliki banyak manfaat di bidang medis, farmasi, industri makanan maupun pertanian karena kemampuannya untuk menghidrolisis kitin menjadi $\mathrm{N}$-asetilglukosamin (Herdyastuti et al., 2009 a). Permintaan kitinase yang tinggi memacu ketersediaannya di pasar dengan harga murah, tahan terhadap berbagai faktor lingkungan serta proses produksi yang sederhana.

Bakteri mengalami pertumbuhan yang cepat dan variasi rekayasa genetika dapat dilakukan agar dapat menghasilkan enzim yang tahan terhadap berbagai pengaruh fisik maupun kimia di lingkungan sekitarnya. Kemampuan bakteri tersebut diharapkan berpotensi untuk membantu memenuhi kebutuhan kitinase di pasar (Dewi, 2008).

Bakteri kitinolitik selama pertumbuhannya membutuhkan sumber nutrisi berupa kitin. Kitin komersial yang ada di pasar kurang efektif untuk digunakan karena harganya mahal (Pujiyanto danWijanarka, 2004), sehingga kitin yang ada pada cangkang rajungan dapat digunakan sebagai alternatif sumber kitin yang lain. Sumber kitin dari cangkang rajungan berpotensi untuk digunakan karena harganya murah dan mudah didapat (Saima et al., 2013). Hal ini memerlukan studi lebih lanjut terkait substrat kitin dari cangkang rajungan mampu menghasilkan aktivitas kitinase yang sama seperti pada kitin komersial atau tidak.

Produksi kitinase oleh bakteri kitinolitik selain dipengaruhi oleh sumber nutrisi juga dipengaruhi oleh suhu dan $\mathrm{pH}$ lingkungan. Nilai aktivitas enzim yang tinggi dapat diperoleh jika proses produksi enzim berada pada suhu dan $\mathrm{pH}$ optimum.

Latar belakang di atas menjadikan perlunya dilakukan penelitian terkait kemampuan bakteri kitinolitik dari kawasan Geotermal Dieng untuk memproduksi kitinase pada sumber kitin komersial dan kitin cangkang rajungan serta $\mathrm{pH}$ optimal untuk mencapai aktivitas enzim tertinggi..

\section{BAHAN DAN METODE}

Bahan. Bahan yang digunakan dalam penelitian ini yaitu: sampel lumpur berair dari kawasan Geotermal Dieng (Kawah Sikidang dan PAD 29 PT. Geodipa Energi), medium agar kitin $\left(0,05 \% \quad \mathrm{MgSO}_{4} .7 \mathrm{H}_{2} \mathrm{O}, \quad 0,07 \% \quad \mathrm{~K}_{2} \mathrm{HPO}_{4}, \quad 0,1 \%\right.$ ekstrak yeast, $0,5 \%$ koloid kitin rajungan dan 1,5\% agar), medium produksi $(0,1 \%$ pepton, $0,1 \%$ ekstrak yeast, 0,5\% koloid kitin (perlakuan), 0,1\% $\mathrm{K}_{2} \mathrm{HPO}_{4}, \quad 0,1 \% \quad \mathrm{MgSO}_{4} .7 \mathrm{H}_{2} \mathrm{O}, \quad 0,01 \%$ $\mathrm{MnSO}_{4} \cdot \mathrm{nH}_{2} \mathrm{O}$ ), reagensia Dinitro Salicyclic Acid (DNS), N-Asetil D-glukosamin, buffer fosfat 0,1 $\mathrm{M}$ pH 6, 7 dan 8, $\mathrm{HCl}$ pekat, $\mathrm{NaOH}$ dan akuades.

Preparasi Koloid Kitin. Koloid kitin komersial dan kitin cangkang rajungan dibuat dengan cara $20 \mathrm{~g}$ (kitin komersial dan cangkang rajungan) ditambah $300 \mathrm{~mL} \mathrm{HCl}$ pekat dan dihomogenkan kemudian diinkubasi di dalam lemari pendingin selama 24 jam. Larutan ditambah aquades $200 \mathrm{ml}$ yang sudah didinginkan dengan suhu $4{ }^{\circ} \mathrm{C}$ selama satu malam, selanjutnya disaring dengan glass wool. Filtratdinetralkan dengan $12 \mathrm{~N}$ $\mathrm{NaOH}$ sampai $\mathrm{pH}$ 7. Larutan disentrifugasi dengan kecepatan 4.000 rpmselama 10 menit. Endapan yang diperoleh dibilas dengan akuades steril dan disentrifugasi dengan kecepatan $4.000 \mathrm{rpm}$ selama 10 menit (Saskiawan dan Handayani., 2011).

Isolasi dan Seleksi Bakteri Kitinolitik. Isolasi bakteri kitinolitik dari wilayah Geotermal Dieng dilakukan dengan metode screening. Sampel lumpur berair dari wilayah Geotermal Dieng sebanyak $200 \mu 1$ diencerkan pada $1 \mathrm{ml}$ larutan fisiologis 0,85\% kemudian dicawankan pada media agar kitin dengan cara spread plate dan diinkubasi pada suhu ruang $\left(28^{\circ} \mathrm{C}\right)$ selama 14 hari (Purkan et al., 2014). Isolat yang stabil membentuk zona bening diseleksi dengan cara ditotolkan pada media agar kitin dan diinkubasi pada suhu ruang selama 96 jam. Isolat dengan 
indeks kitinolitik tertinggi digunakan pada tahap produksi kitinase. Indeks kitinolitik yaitu perbandingan antara diameter zona bening dengan diameter koloni untuk memperoleh isolat potensial (Dewi, 2008). Menurut Suryadi et al., (2013), rumus indeks kitinolitik adalah sebagai berikut:

$$
\mathrm{IK}=\mathrm{D} \text {. Zona Bening / D. Koloni }
$$

Pembuatan Medium Kultur Bakteri. Medium kultur sebanyak $50 \mathrm{ml}$ terdiri dari $0,05 \mathrm{~g}$ pepton, 0,05 g ekstrak yeast, 0,25 g koloid kitin (perlakuan), $0,05 \mathrm{~g} \mathrm{~K}_{2} \mathrm{HPO}_{4}, 0,05 \mathrm{~g} \mathrm{MgSO}_{4} .7 \mathrm{H}_{2} \mathrm{O}$, dan $0,005 \mathrm{~g} \mathrm{MnSO}_{2} \cdot \mathrm{nH}_{2} \mathrm{O}$. Bahan dicampur, kemudian dilarutkan pada buffer fosfat $\mathrm{pH} 6,7$ dan 8 serta disterilkan selama 20 menit pada suhu $121^{\circ} \mathrm{C}$ di autoklaf. Nilai pH diukur kembali untuk memastikan ketepatannya (Purkan et al., 2014).

Kurva Pertumbuhan dan Produksi Kitinase. Seratus mililiter medium kitin cair $\mathrm{pH} 7$ (komposisi sama seperti media isolasi, tanpa agar) diinokulasi dengan 2 oose isolat bakteri (Dewi, 2008). Kultur bakteri diinkubasi pada suhu ruang dengan penggojogan $120 \mathrm{rpm}$ sampai OD mencapai 0,5 dengan $\lambda 580 \mathrm{~nm}$ (Pujiyanto et al., 2008). Kultur sebanyak 5\% (v/v) dipindahkan ke $50 \mathrm{~mL}$ media produksi kitin cair dengan $\mathrm{pH}$ berbeda $(6,7$ dan 8), lalu diinkubasi pada kondisi yang sama. Pengukuran OD (Optical Density) dilakukan setiap 6 jam sekali dengan pengambilan kultur sebanyak $5 \mathrm{~mL}$ sampai 48 jam. Nilai OD diukur dengan spektrofotometer pada $\lambda 580 \mathrm{~nm}$ setelah koloid kitin pada medium mengendap. Kurva pertumbuhan dibuat dengan memplot nilai OD $580 \mathrm{~nm}$ terhadap waktu (Purkan et al., 2014). Pengukuran produksi enzim dilakukan dengan pengambilan kultur dari hasil sampling setiap 6 jam sekali sebanyak 1,5 ml, kemudian disentrifugasi pada $4.000 \mathrm{rpm}$ selama 10 menit. Supernatan yang diperoleh merupakan enzim kasar yang digunakan untuk uji aktivitas kitinase (Purkan et al., 2014).

Uji Aktivitas Kitinase. Uji aktivitas kitinase dilakukan dengan membuat sampel, kontrol dan blanko. Sampel dibuat dengan 0,75 $\mathrm{mL}$ ekstrak kasar enzim ditambah dengan 0,75 $\mathrm{mL}$ substrat $1 \%(\mathrm{~b} / \mathrm{v})$ koloid kitin dan $0,75 \mathrm{ml}$ buffer fosfat $\mathrm{pH} 7$ dalam tabung reaksi. Kontrol dibuat dengan komponen sama seperti sampel, namun sebelum inkubasi diinaktivasi dahulu pada suhu $100^{\circ} \mathrm{C}$ selama 10 menit sedangkan blanko berisi $1,5 \mathrm{ml}$ akuades serta $0,75 \mathrm{ml}$ buffer fosfat pH 7. Sampel, kontrol dan blanko diinkubasi pada suhu $50^{\circ} \mathrm{C}$ selama 30 menit. Sampel, kontrol dan blanko ditambah $0,75 \mathrm{~mL}$ reagen DNS, lalu dipanaskan pada suhu $100^{\circ} \mathrm{C}$ selama 10 menit. Campuran didinginkan dan ditambah $0,75 \mathrm{~mL}$ akuades (Mago, 2015) serta diukur absorbansinya pada $\lambda 540 \mathrm{~nm}$ (SarahdanPutro., 2010).Satu unit aktivitas kitinase adalah jumlah enzim yang mampu menghasilkan $1 \mu \mathrm{mol}$ gula reduksi per menit pada suhu $50^{\circ} \mathrm{C}$ (Wang et al., 2012). Aktivitas enzim ditentukan berdasar konsentrasi gula reduksi yang diperoleh menggunakan kurva standart GlcNAC. Menurut Mago (2015), aktivitas kitinase dinyatakan dengan rumus:

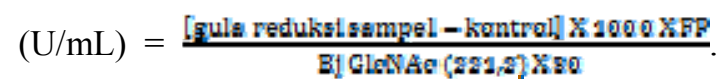

\section{HASIL DAN PEMBAHASAN}

Isolasi dan Seleksi Bakteri Kitinolitik. Hasil isolasi diperoleh 11 isolat dari sampel Kawah Sikidang dan 1 isolat dari PT Geodipa Energi, Dieng. Bakteri yang diisolasi dari PT Geodipa Energi mampu tumbuh pada pH media 7, keadaan ini berbeda dengan $\mathrm{pH}$ yang ada di habitat alaminya ( $\mathrm{pH} \mathrm{6),} \mathrm{karena} \mathrm{bakteri} \mathrm{mampu} \mathrm{hidup} \mathrm{di}$ suhu tinggi dengan membentuk spora yang tahan terhadap panas dan asam (Hamaouda et al., 2002). Dua belas isolat yang didapat ternyatahanya empat yang stabil membentuk zona bening.

Isolat yang memiliki zona bening di sekitar koloni dianggap sebagai bakteri kitinolitik, karena hanya bakteri yang memproduksi kitinase yang dapat mengurai substrat kitin pada medium (Chang et al., 2004). Zona bening di terbentuk karena proses pemecahan substrat kitin menjadi senyawa sederhana setelah disekresikannya kitinase oleh bakteri (Suryadi et al., 2013). Empat isolat selanjutnya dikarakterisasi berdasarkan bentuk morfologi koloni dan morfologi sel. Hasil karakterisasi dapat dilihat pada Tabel 1. dan hasil isolasi serta pewarnaan Gram pada Gambar 1. 
Tabel 1. Karakteristik Morfologi Isolat Bakteri Kitinolitik

\begin{tabular}{lllllll}
\hline \multirow{2}{*}{ Isolat } & \multicolumn{4}{c}{ Morfologi Koloni } & \multicolumn{2}{c}{ Morfologi Sel } \\
\cline { 2 - 6 } & Bentuk & Tepi & Elevasi & Warna & Bentuk & Gram \\
\hline KSR 121 & Irregular & Lobate & Flat & Putih & Basil & Negatif \\
GDR 1 & Irregular & Lobate & Flat & Putih & Kokus & Negatif \\
KSR HA 25 & Circular & Entire & Flat & Putih & Basil & Negatif \\
KSR HA 31 & Circular & Entire & Flat & Putih & Basil & Negatif \\
\hline
\end{tabular}

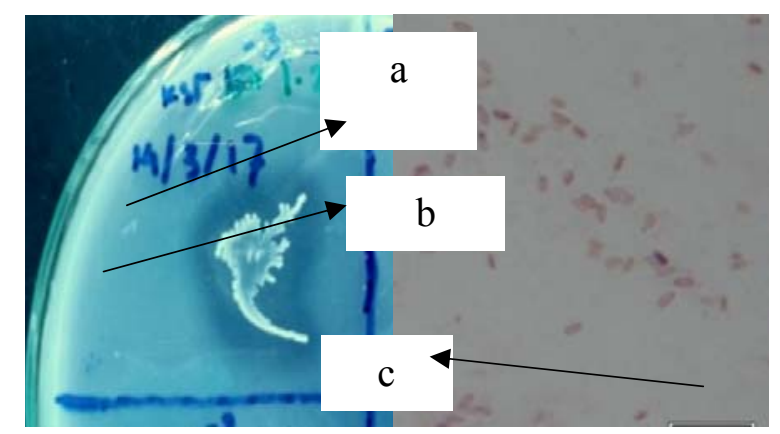

Gambar 1. Morfologi Koloni Isolat KSR 121 (a) Zona Bening (b) Koloni Bakteri (c) Basil, Gram Negatif

Tabel 2. Indeks Kitinolitik Isolaat Bakteri Kitinolitik

\begin{tabular}{|c|c|c|c|c|c|c|c|c|c|c|c|c|c|}
\hline \multirow[t]{2}{*}{ Isolat } & \multicolumn{4}{|c|}{$\begin{array}{l}\text { D. koloni (cm) } \\
\text { Jam ke }\end{array}$} & \multicolumn{4}{|c|}{$\begin{array}{c}\text { D. zona bening }(\mathrm{cm}) \\
\text { Jam ke }\end{array}$} & \multicolumn{4}{|c|}{$\begin{array}{c}\text { Indeks Kitinolitik }(\mathrm{cm}) \\
\text { Jam ke }\end{array}$} & \multirow{2}{*}{$\begin{array}{c}\text { Indeks } \\
\text { Kitinolitik }(\mathrm{cm})\end{array}$} \\
\hline & 24 & 48 & 72 & 96 & 24 & 48 & 72 & 96 & 24 & 48 & 72 & 96 & \\
\hline KSR 121 & 1 & 1,2 & 1,2 & 1,2 & - & 1,4 & 1,7 & 1,8 & - & 1,2 & 1,4 & 1,5 & 1,4 \\
\hline GDR 1 & 0,5 & 0,5 & 0,7 & 0,7 & - & 0,6 & 0,9 & 1 & - & 1,2 & 1,3 & 1,4 & 1,3 \\
\hline KSR HA 25 & 0,6 & 0,9 & 1 & 1,1 & - & - & 1,1 & 1,2 & - & - & 1,1 & 1,0 & 1,1 \\
\hline KSR HA 31 & 0,4 & 0,7 & 0,9 & 0,9 & - & - & - & - & - & - & - & - & - \\
\hline
\end{tabular}

Seleksi bakteri kitinolitik dilakukan untuk mendapatkan isolat yang mampu menghidrolisis kitin paling besar. Proses ini dilakukan melalui analisis kualitatif dengan indeks kitinolitik. Hasil indeks kitinolitik dapat dilihat pada Tabel 2.Berdasarkan hasil pengukuran indeks kitinolitik, diketahui bahwa nilai indeks kitinolitik yang dihasilkan setiap isolat berbeda-beda. Nilai indeks kitinolitik terbesar dimiliki oleh isolat KSR 121, sehingga digunakan untuk produksi kitinase.

Pola Pertumbuhan Isolat KSR 121. Pola pertumbuhan isolat KSR 121 mulai terjadi pada jam ke 0 hingga jam ke 6. Nilai absorbansi yang tinggi pada jam ke 0 disebabkan karena adanya biomassa lain, yaitu kitin pada media produksi yang menyebabkannya menjadi keruh (Reynolds,
1954).Kurva mengalami peningkatan kembali setelah jam ke 24 hingga jam ke 42 dan turun pada jam ke 48. Hal ini terjadi karena adanya produk metabolite sekunder dari dalamsel bakteri selama pertumbuhan (Dutta, 2008).

Perlakuan K2P3 menunjukkan nilai absorbansi paling tinggi untuk pertumbuhan isolat KSR 121. Faktor yang mempengaruhi adalah jenis sumber kitin pada media produksi sama dengan media isolasi dan starter serta $\mathrm{pH}$ media produksi $(\mathrm{pH} 8)$ cenderung mendekati $\mathrm{pH}$ habitat aslinya, yaitu 7,6. Kemungkinan lain yang mendukung yaitu bakteri bersifat toleran alkali, sehingga dapat tumbuh pada $\mathrm{pH}$ basa namun dapat tumbuh pula pada $\mathrm{pH}$ netral 

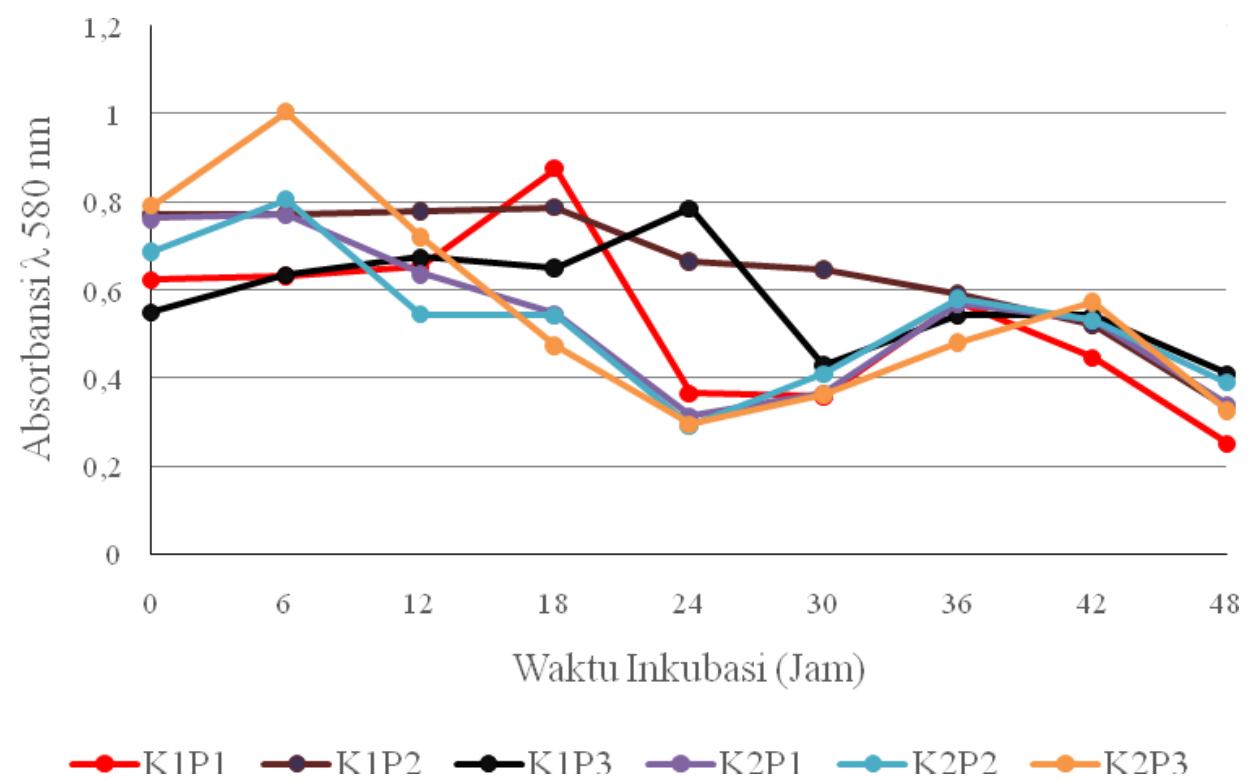

Gambar 2. Kurva Pertumbuhan Isolat KSR 121

Kitin cangkang rajungan lebih bagus untuk pertumbuhan isolat KSR 121 karena kitin pada cangkang rajungan lebih tinggi dibandingkan dengan kitin komersial (udang), sehingga dapat memenuhi kebutuhan nutrisi bakteri. Hal ini sesuai dengan hasil penelitian Rosandari dan Rachman (2012), bahwa cangkangudang mengandung kitin sebesar 20-30\% sedangkan kadar kitin tepung cangkang rajungan sebesar 37,40\% (Rochima, 2007). Hasil di atas didukung pula dari hasil penelitian Jabeen dan Qazi (2014) yang menyatakan bahwa aktivitas kitinase yang dihasilkan Bacillus cereus JF68 pada media kitin rajungan sebesar 2.831,75 U/mL, sedangkan menurut Natsir et al. (2012), Bacillus licheniformis yang ditumbuhkan pada media kitin udang memiliki aktivitas kitinase sebesar $0,48 \mathrm{U} / \mathrm{mL}$.

Aktivitas Kitinase. Berdasarkan uji statistik menunjukkan bahwa bahwa perlakuan jenis sumber kitin, $\mathrm{pH}$, maupun interaksi jenis sumber kitin dan $\mathrm{pH}$ tidak berpengaruh terhadap aktivitas enzim $(\mathrm{P}>0,05)$. Hal ini dapat terjadi karena kemungkinan nilai $\mathrm{pH}$ koloid kitin setelah proses pencucian tidak tepat 7 , karena setelah pencucian dengan aquades tidak dilakukan pengukuran nilai $\mathrm{pH}$ kembali, sehingga menyebabkan proses hidrolisis kitin tidak sempurna. Adanya kandungan garam pada koloid kitin karena proses pencucian yang belum maksimal juga dapat mempengaruhi nilai aktivitas enzim. Menurut Soeka danSulistiani (2011), kondisi-kondisi yang menyebabkan denaturasi protein seperti konsentrasi garam yang tinggi dan nilai $\mathrm{pH}$ yang terlalu tinggi atau terlalu rendah akan menghilangkan aktivitas enzim.

Kitinase yang dihasilkan oleh isolat bakteri KSR 121 memiliki nilai aktivitas enzim tertinggi 0,125 $\mathrm{U} / \mathrm{ml}$. Nilai aktivitas ini diperoleh pada perlakuan K2P2 (koloid kitin rajungan, $\mathrm{pH} 7$ ) dengan waktu inkubasi 24 jam. Hasil pengujian aktivitas kitinase ini dapat dilihat pada Gambar 3 


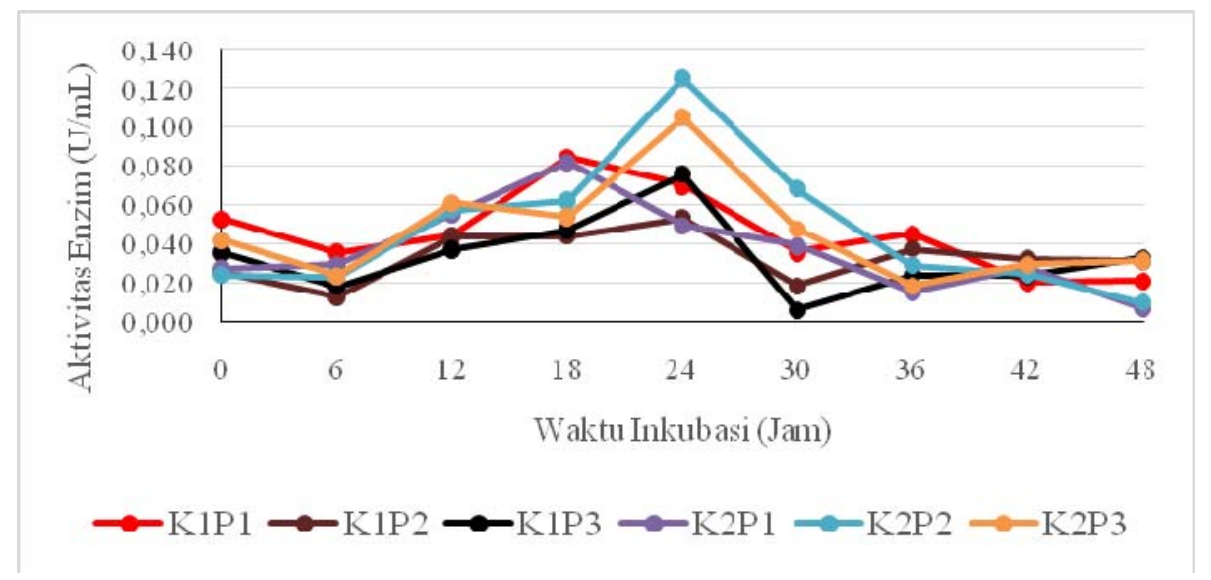

Gambar 3. Kurva Aktivitas Kitinase Isolat KSR 121

Berdasarkan gambar di atas diketahui bahwa sintesis kitinase tertinggi terjadi pada substrat kitin rajungan $\mathrm{pH}$ 7. Hal ini terjadi karena pada kondisi tersebut sisi aktif enzim mengalami ionisasi asam amino, sehingga terjadi interaksi yang kuat antara enzim dengan substrat kitin rajungan (Soeka dan Sulistiani, 2011).Waktu produksi kitinase tertinggi tidak sesuai dengan kurva pertumbuhan isolat KSR 121, di mana pertumbuhan tertinggi pada jam ke 6 dan mulai mengalami penurunan saat jam ke 24 . Hal ini karena adanya kemungkinan kitin dipecah oleh lisozim yang dihasilkan oleh bakteri saat mengalami lisis. Keadaan tersebut dapat terjadi pada bakteri saat memasuki fase kematian. Lisozim akan memutus ikatan $\beta-1,4$ antara asam$\mathrm{N}$-asetil glukosamin dengan asam- $\mathrm{N}$-asetil muramat pada dinding sel bakteri yang menyerupai

struktur polimer $\beta-1,4 \mathrm{~N}$-asetilglukosamin dari kitin (RobertsdanSelitrennikoff., 1988).

Penyebab lainnya yaitu karena kitinase merupakan enzim ekstraseluler, sehingga enzim tetap akan berada dalam medium produksi meskipun jumlah bakteri mulai berkurang. Sulitnya senyawa kitin untuk didegradasi mengakibatkan kitinase pada medium terus menerus mendegradasi kitin menjadi $\mathrm{N}$-asetil glukosamin, sehingga $\mathrm{N}$-asetil glukosamin akan terakumulasi dan menunjukkan nilai absorbansi yang tinggi pada saat pengujian aktivitas enzim (Hamid et al., 2013).

Produksi enzim pada jam ke 0 tinggi karena adanya enzim kitinase yang dihasilkan dari biakan starter (Apriani, 2008), selanjutnya produksi enzim turun pada jam ke 6, karena akumulasi GlcNAc sehingga menghambat produksi kitinase (Donderski dan Trzebiatowska, 2000). Adanya GlcNAc pada media digunakan oleh bakteri untuk membantu proses pembentukan peptidoglikan pada dinding sel, sehingga pada jam berikutnya produksi enzim meningkat kembali (Apriani, 2008) 


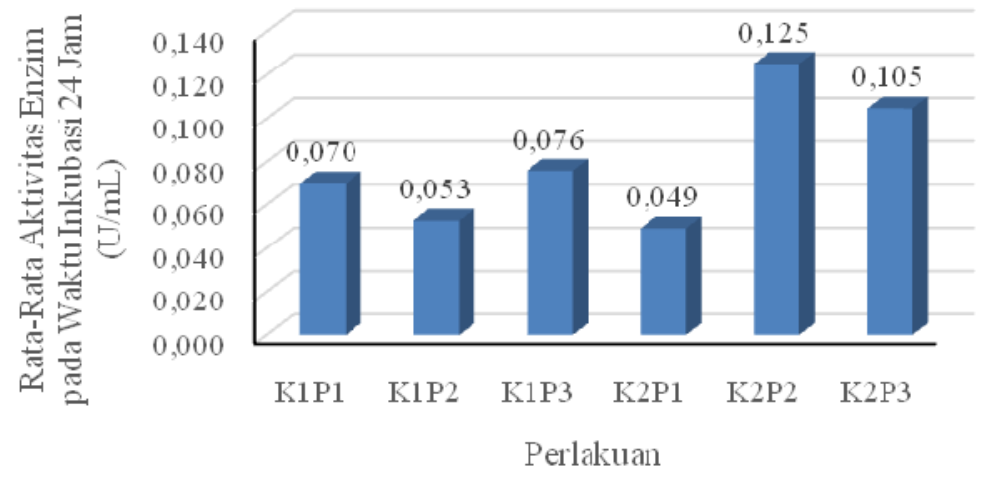

Gambar 4. Diagram Rata-Rata Aktivitas Kitinase oleh Isolat KSR 121 pada Waktu Inkubasi 24 Jam

Berdasarkan diagram pada Gambar 4, diketahui bahwa nilai aktivitas enzim perlakuan $\mathrm{K} 2 \mathrm{P} 2(0,125 \mathrm{U} / \mathrm{ml})$ lebih tinggi dibandingkan perlakuan K1P1 $(0,070 \mathrm{U} / \mathrm{ml}), \mathrm{K} 1 \mathrm{P} 2(0,053 \mathrm{U} / \mathrm{ml})$, K1P3 $(0,076 \mathrm{U} / \mathrm{ml}), \mathrm{K} 2 \mathrm{P} 1(0,049 \mathrm{U} / \mathrm{ml})$ maupun K2P3 $(0,105 \mathrm{U} / \mathrm{ml})$ di jam ke 24 . Faktor yang mempengaruhi yaitu kitin yang digunakan masih mengandung protein atau mineral akibat belum sempurnanya proses deproteinasi dan demineralisasi, sehingga mineral-mineral tersebut merusak protein enzim dan menurunkan proses katalisis (Herdyastuti et al.,2009 c).

\section{KESIMPULAN}

Berdasarkan hasil penelitian yang dilakukan dapat disimpulkan bahwa isolasi sampel lumpur berair dari kawasan Geotermal Dieng didapatkan tiga bakteri kitinolitik, yaitu isolat bakteri KSR 121, GDR 1 dan KSR HA 25. Isolat KSR 121 menghasilkan indeks kitinolitik tertinggi, sehingga terpilih untuk digunakan pada tahap produksi kitinase. Hasil uji statistik aktivitas kitinase oleh isolat KSR 121 pada jam ke 24 menunjukkan perlakuan jenis sumber kitin, variasi $\mathrm{pH}$ media produksi dan interaksi antara perlakuan jenis sumber kitin dengan $\mathrm{pH}$ media produksi yang diberikan tidak berbeda nyata, namun pertumbuhan tertinggi isolat bakteri KSR 121 terjadi pada perlakuan jenis substrat kitin rajungan $\mathrm{pH} \quad 8$, sedangkan aktivitas enzim tertinggi diperoleh pada jenis substrat kitin rajungan $\mathrm{pH} 7$.

\section{DAFTAR PUSTAKA}

Apriani, L. 2008. Seleksi Bakteri Penghasil Enzim Kitinolitik serta Pengujian beberapa Variasi Suhu dan $\mathrm{pH}$ untuk Produksi Enzim. Skripsi. FMIPA, UI. Depok.

Bird, P. 2003. An Updated Digital Model of Plate Boundaries. Elec J. Ear. Sci. 4(3): 15252027.

Chang S. C., J. T. Wang, P. Vandamme, J. H. Hwang. P. S Chang dan W. M Chen. 2004. Chitinimonas taiwanensis gen. nov., sp. nov., a Novel Chitinolytic Bacterium Isolated from a Freshwater Pond for Shrimp Culture. J. System. Appl. Microbiol. 27: 4349.

Dewi, I. M. 2008. Isolasi Bakteri dan Uji Aktivitas Kitinase Termofilik Kasar dari Sumber Air Panas Tinggi Raja, Simalungun, Sumatera Utara. Tesis. Program Pascasarjana, Universitas Sumatera Utara. Medan.

Donderski, W. dan M. Trzebiatowska. 2000. Influence of PHysical and Chemical Factors on the Activity of Chitinases Produced by Planktonic Bacteria Isolated from Jeziorak Lake. PJES. 9(2): 77-82.

Dutta, R. 2008. Fundamentals of Biochemistry Engineering. Springer. India.

Hamaouda, T., A. Y. Shih dan J.R Baker. 2002. A Rapid Staining Technique for the Detection of the Initiation of Germination of Bacterial Spores. J. Letter in App. Microb. 34(1): 8690. 
Herdyastuti, N., T. J. Raharjo, Mudasir dan S. Matsjeh. 2009 a. Chitinase and Chitinolytic Microorganism: Isolation, Characterization and Potential. Indo. J. Chem. 9(1): 37-47.

Herdyastuti, N., S. E. Cahyaningrum dan T. J. Raharjo. 2009 c. Eksplorasi Bakteri Penghasil Kitinase dari Lumpur Pertanian dan Keragaman Gen Pengyandi Bakteri Kitinolitik sebagai Gen Biokontrol. Laporan Penelitian. Universitas Negeri Surabaya. Surabaya

Jabeen, F dan J. I Qazi. 2014. Isolation of Chitinase Yielding Bacillus cereus JF68 from Soil Employing an Edible Crab Shell Chitin. JSI. 73(1): 771-776.

Mago, Oktavius YosepH Tuta. 2015. Optimasi Biokonversi Kitin dari Cangkang Udang Menggunakan Bakteri Kitinolitik dari Sumber Air Panas Gedong Songo Bandungan Kabupaten Semarang. Tesis. UNDIP. Semarang.

Natsir, H., A. R. Patong, M. T. Suhartono dan A. Ahmad. 2012. Produksi dan Aplikasi Kitinase dari B. licheniformisHsa3-1a dalam Menghidrolisis Kitin dari Limbah Udang dan Dinding Sel Jamur Ganodermasp. Laporan Penelitian. Departemen Kimia, FMIPA, UNHAS. Makassar.

Pujiyanto, S. dan Wijanarka. 2004. Pemanfaatan Limbah Cangkang Udang sebagai Media Produksi Enzim Kitinase. Laporan Penelitian. Fakultas Matematika dan Ilmu Pengetahuan Alam, Universitas Diponegoro. Semarang.

Pujiyanto, S., E. Kusdiyantini dan M. Hadi. 2008. Isolasi dan Seleksi Bakteri Kitinolitik Isolat Lokal yang Berpotensi untuk Mengendalikan Larva Nyamuk Aedes aegypti L. J. Biodevirsitas. 9(1): 5-8.

Purkan, B., Azizah, A. Baktir dan S. Sumarsih. 2014. Eksplorasi Bakteri Kitinolitik dari Sampah Organik: Isolasi dan Karakterisasi Enzim Kitinase. JM. 9(2): 128-135.

Roberts, W. K. and C. P. Selitrennikoff. 1988. Plant and Bacterial Chitinases Differ in
Antifungal Activity. J. General Microb. 134(1): 169- 176

Rochima, Emma. 2007. Karakterisasi Kitin dan Kitosan Asal Limbah Rajungan Cirebon Jawa Barat. Buletin Teknologi Hasil Perikanan. 5(1):1-14.

Rosandari, T. dan I. N. Rachman. 2012. Pemanfaatan Limbah Cangkang Udang (Penaeus sp.) untuk Penganekaragaman Makanan Ringan Berbentuk Stik. Laporan Penelitian. Program Studi Teknologi Industri Pertanian, Institut Teknologi Indonesia. Serpong.

Reynolds, D. M. 1954. Exocellular Chitinase from a Streptomyces sp. J . gen. MicrobioE. 11(1): 150-159.

Saima, M. Kuddus, Roohi dan vel Chitinolytic Bacteria and Production Optimization of Extracellular Chitinase. J. of Gen. Eng. and Biotech. 11(1): 39-46.

Sarah, S. R. Putra dan H. S. Putro. 2010. Isolasi $\alpha-$ Amilase Termostabil dari BakteriBacillus stearothermophilus. Prosiding Skripsi. Jurusan Kimia, FMIPA, ITS.

Saskiawan, I. dan R. Handayani. 2011. Hidrolisis Kitin melalui Fermentasi Semi Padat untuk Produksi N-Asetilglukosamina. Berita Biologi: JIH. 10(6): 721-728.

Soeka, Y. S. dan Sulistiani. 2011. Seleksi, Karakterisasi, dan Identifikasi Bakteri Penghasil Kitinase yang Diisolasi dari Gunung Bromo Jawa Timur. J. Natur Indonesia. 13(2): 155-161

Suryadi, Y., T. P. Priyatno, M. Samudra, D. N. Susilowati, N. Lawati dan E. Kustaman. 2013. J. Agro Biogen. 9(2):77-84.

Wang, S., Ye, X.,Chen, J dan Rao, P. 2012. A Novel Chitinase Isolated from Vicia faba and its Antifungal Activity. J. Food Research Int. 45: 116-122. 